\title{
STRATEGI KOMUNIKASI BENCANA PADA MASYARAKAT KABUPATEN BUTON SELATAN
}

\author{
Ansar Suherman ${ }^{1}$ \\ Fakulta Ilmu Sosial dan Ilmu Politik, Universitas Muhammadiyah Buton \\ Email: ansar.suherman@gmail.com
}

\begin{abstract}
ABSTRAK
Komunikasi dalam bencana tidak saja dibutuhkan dalam kondisi darurat bencana, tapi juga penting pada saat pra bencana.Mempersiapkan masyarakat di daerah rawan bencana tentu harus senantiasa dilakukan. Selain informasi yang memadai tentang potensi bencana di suatu daerah, pelatihan dan internalisasi kebiasaan menghadapi situasi bencana juga harus dilakukan secara berkelanjutan Teknik pengumpulan data yang digunakan adalah wawancara mendalam, observasi, dan studi dokumentasi. Hasil penelitian yang telah dilakukan menunjukkan adanya strategi komunikasi interaktif dalam kesiapan menghadapi bencana, yaitu : Penentuan aparat desa/tokoh masyarakat sebagai komunikator/ sumber yang kredibel, Pemilihan pesan yang mudah diterima oleh masyarakat di kawasan kaki gunung Burangrang, Penggunaan media komunikasi yang sesuai dengan karakteristik masyarakat desa, Pemahaman karakteristik masyarakat desa, Mengatasi hambatan komunikasi yang terjadi selama pelaksanaan strategi komunikasi tersebut.
\end{abstract}

Kata Kunci: Startegi, komunikasi, Bencana, Buton Selatan

\section{THE COMMUNICATIONS STRATEGY DISASTER THE SOCIETY OF DISTRICT BUTON SOUTH}

\begin{abstract}
The communication in a disaster not only is needed in an emergency disaster, but also important at the pre bencana.mempersiapkan people in the disaster prone. certainly must always be doneIn addition to adequate information about potential catastrophe in a region, training and internalization of the habit of facing a situation disaster were also to be done sustainably data collection techniques used are in depth interviews, observation and study. documentationThe research has made indicate the presence of the communications strategy in disaster preparedness, interactive namely: the determination of village officials/community figures as a communicator, credible source the election a message that is easily accepted by the community in the area of the mountain burangrang, the use of the media communication that is in accordance with the characteristics of the village community, understanding the characteristics of the village community, overcoming obstacles the com for the implementation of the communication strategy.
\end{abstract}

Keywords: Startegi, Communication, Disaster, Buton South 
Korespondensi: Ansar Suherman, S.IP., M.I.Kom. Universitas Muhammadiyah Buton. Alamat: Jl. Betoambari No. 36 Kota Baubau Sulawesi Tenggara kode Pos 93717. No. HP, WhatsApp: 08114030818 Email: ansar.suherman@gmail.com

\section{PENDAHULUAN}

Penanggulangan bencana harus didukung dengan berbagai pendekatan baik soft power maupun hard power untuk mengurangi resiko dari bencana. Pendekatan soft power adalah dengan mempersiapkan kesiagaan masyarakat melalui sosialisasi dan pemberian informasi tentang bencana.

Komunikasi dalam bencana tidak saja dibutuhkan dalam kondisi darurat bencana, tapi juga penting pada saat dan pra bencana. Mempersiapkan masyarakat di daerah rawan bencana tentu harus senantiasa dilakukan. Selain informasi yang memadai tentang potensi bencana di suatu daerah, pelatihan dan internalisasi kebiasaan menghadapi situasi bencana juga harus dilakukan secara berkelanjutan. Tapi harus diingat, informasi berlimpah saja tidak cukup untuk menyadarkan warga atas bahaya bencana yang mengancam.

Terlepas dari cara yang dilakukannya untuk berkomunikasi, maka setiap individu pun akan memainkan perannya masing-masing agar tujuan yang diharapkannya pun tercapai. Oleh karena itu, untuk mencapai tujuan komunikasinya inilah, maka diperlukan sebuah strategi komunikasi yang efektif demi keberhasilan tujuan yang diharapkan.

Istilah strategi sudah menjadi istilah yang sering digunakan oleh masyarakat untuk menggambarkan berbagai makna seperti suatu rencana, taktik atau cara untuk mencapai apa yang diinginkan. Strategi pada hakikatnya adalah perencanaan (planning) dan manajemen (management) untuk mencapai suatu tujuan.

Tetapi, untuk mencapai tujuan tersebut, strategi tidak berfungsi sebagai peta jalan yang hanya menunjukkan arah saja, melainkan harus mampu menunjukkan bagaimana taktik operasionalnya. (Effendy, 2003:32)

Unsur komunikasi yang turut menjadi faktor penentu keberhasilan dalam mencapai tujuan pembangunan adalah pelaku komu-nikasi baik dari unsur pemerintah lokal maupun masyarakat. Dimensi-dimensi yang menjadi pertimbangan untuk orang yang menyampaikan pesan (komunikator) adalah kredibilitas, keahlian, dapat dipercaya, daya tarik, karismatik, kewibawaan, pemenuhan. Unsur berikutnya adalah komunikan (receiver), (Abadi \& Mahendrawati: 2012).

Berhasil tidaknya suatu pembangunan yang berkaitan dengan masyarakat luas bergantung pada bagaimana sebenarnya strategi komunikasi yang digunakan oleh organisasi baik pemeritah maupun swasta. Strategi komunikasi pada hakikatnya merupakan paduan perencanaan komunikasi (communication planning) dengan memanajemen komunikasi (communication management) untuk mencapai suatu tujuan yang telah ditetapkan (Effendy; 2003 :301).

Strategi komunikasi adalah serangkaian tindakan yang direncanakan dengan baik untuk mencapai tujuan tertentu dengan menggunakan metode, teknik, dan pendekatan komunikasi. Ada tiga pendekatan dalam strategi komunikasi menurut Berger (Griffin, 2006:130), yaitu strategi pasif, aktif, dan interaktif. 
Di antara ketiga strategi tersebut, pendekatan interaktif lebih banyak disarankan dalam pembangunan dunia ketiga karena pendekatan ini tampak lebih mengedepankan nilai-nilai humanis serta budaya baru yang pada gilirannya mampu mengubah mind-set masyarakat tentang pembangunan. Model pembangunan dengan menggunakan pendekatan ini lebih mengedepankan pada proses pendidikan masyarakat agar memiliki consciousness.

Penyadaran inilah yang kemudian dapat digunakan untuk memformulasikan dan mengorganisasikan solusi permasalahan yang dialami masyarakat secara lebih baik.

Usaha penanggulangan resiko bencana akibat kerusakan lingkungan dan menjaga kelestarian lingkungan merupakan salah satu tujuan yang sangat penting dilakukan dan tertuang dalam tujuan dalam butir tujuan Pembangunan Berkelanjutan (Sustainable Development Goals/SDGs) yaitu melindungi, memulihkan dan memajukan penggunaan ekosistem bumi, mengelola hutan secara berkelanjutan, memerangi desertifikasi dan menghentikan kepunahan keanekaragaman hayati. Oleh karena itu, diperlukan adanya strategi komunikasi dalam mitigasi bencana longsor bagi masyarakat di desa tersebut.

Untuk menurunkan resiko bencana, tentu memerlukan suatu strategi komunikasi yang efektif agar kegiatan penurunan resiko bencana dapat berjalan secara optimal

\section{METODE PENELITIAN}

Dalam penelitian ini, penulis menggunakan metode studi kasus. Definisi lain mengenai studi kasus diungkapkan oleh Robert K. Yin. Yin menyatakan bahwa studi kasus merupakan suatu inkuiri empiris yang menyelidiki fenomena di dalam konteks kehidupan nyata, bilamana batasbatas antara fenomena dan konteks tidak tampak dengan tegas dan dimana multi sumber bukti dimanfaatkan (Yin, 2006: 18). Studi kasus merupakan strategi yang lebih cocok bila pokok pertanyaan suatu penelitian berkenaan dengan how atau why, bila peneliti hanya memiliki sedikit peluang untuk mengontrol peristiwa-peristiwa yang akan diselidiki, dan bilamana fokus penelitiannya terletak pada fenomena kontemporer (masa kini) di dalam konteks kehidupan nyata (Yin, 2006: 19).

Tujuan studi kasus adalah untuk memberikan gambaran secara mendetail tentang latar belakang, sifat-sifat serta karakter-karakter yang khas dari kasus, ataupun status dari individu yang bersangkutan, dan sifat-sifat khas di atas akan dijadikan suatu hal yang bersifat umum (Nazir, 2003: 66). Studi kasus bersifat holistik. Metode ini menganggap kasus sebagai entitas menyeluruh dan bukan sebagai kumpulan bagian-bagian atau kumpulan skor mengenai variabel (Ragin dalam Mulyana, 2002: 203).

Teknik Pengumpulan Data Teknik pengumpulan data yang utama dilakukan dalam penelitian ini adalah observasi, partisipatif dan wawancara mendalam, ditambah kajian dokumen, yang bertujuan tidak hanya untuk menggali data, tetapi juga untuk mengungkap makna yang terkandung dalam latar penelitian. Teknik Penentuan Informan Dalam penelitian ini, penulis menggunakan teknik penentuan informan dengan 
teknik sampling purposive, yaitu memilih informan yang sesuai dengan kebutuhan penulis. Informan yang diambil adalah 4 orang yaitu :

1. Ad, pihak kepala Desa

2. Bd, sekretaris Desa

3. Drn, tokoh masyarakat

4. Rm, warga desa

\section{HASIL DAN PEMBAHASAN}

\section{Konsep Komunikasi Bencana}

Istilah komunikasi bencana belum menjadi konsep popular dalam bidang komunikasi maupun bidang kebencanaan. Meski penelitian komunikasi bencana sendiri telah banyak dilakukan, namun di Indonesia kajian komunikasi terkait bencana baru banyak dilakukan setelah peristiwa bencana alam gempa dan tsunami Aceh tahun 2014. Meski demikian, kesadaran akan pentingnya komunikasi dalam penanganan bencana semakin tinggi belakangan ini. Salah satu titik penting yang menjadi perhatian terkait komunikasi dalam bencana adalah masalah ketidakpastian. Menurut Frank Dance (dalam Littlejohn, 2006: 7), salah satu aspek penting di dalam komunikasi adalah konsep reduksi ketidakpastian. Komunikasi itu sendiri muncul karena adanya kebutuhan untuk mengurangi ketidakpastian, supaya dapat bertindak secara efektif demi melindungi atau memperkuat ego yang bersangkutan dalam berinteraksi secara indivuidual maupun kelompok. Dalam penanganan bencana, informasi yang akurat diperlukan oleh masyarakat maupun lembaga swasta yang memiliki kepedulian terhadap korban bencana.

Komunikasi dalam bencana tidak saja dibutuhkan dalam kondisi darurat bencana, tapi juga penting pada saat dan pra bencana. Sebagaimana dikatakan bahwa komunikasi adalah cara terbaik untuk kesuksesan mitigasi bencana, persiapan, respon, dan pemulihan situasi pada saat bencana. Kemampuan untuk mengkomunikasikan pesan-pesan tentang bencana kepada publik, pemerintah, media dan pemuka pendapat dapat mengurangi resiko, menyelamatkan kehidupan dan dampak dari bencana (Haddow and Haddow, 2008: xiv).

Menurut Haddow dan Haddow (2008:2) terdapat 5 landasan utama dalam membangun komunikasi bencana yang efektif yaitu:

1. Costumer Focus, yaitu memahami informasi apa yang dibutuhkan oleh pelanggan dalam hal ini masyarakat dan relawan. Harus dibangun mekanisme komunikasi yang menjamin informasi disampaikan dengan tepat dan akurat.

2. Leadership commitment, pemimpin yang berperan dalamtanggap darurat harus memiliki komitmen untuk melakukan komunikasi efektif dan terlibat aktif da-lam proses komunikasi.

3. Situational awareness, komunikasi efek-tif didasari oleh pengumpulan, analisis dan diseminasi informasi yang terkendali terkait bencana. Prinsip komunikasi efek-tif seperti transparansi dan dapat di-percaya menjadi kunci.

4. Media partnership, media seperti televi-si, surat kabar, radio, dan lainnya adalah media yang sangat penting untuk menyampaikan informasi secara tepat kepada publik. Kerjasama dengan media menyangkut kesepahaman tentang kebutuhan media dengan tim yang terlatih un-tuk berkerjasama dengan media untuk-mendapatkan informasi dan menyebar-kannya kepada publik. 
Penanggulangan bencana, harus didukung dengan berbagai pendekatan baik soft power maupun hard power untuk mengurangi resiko dari bencana. Pendekatan soft power adalah dengan mempersiapkan kesiagaan masyarakat melalui sosialisasi dan pemberian informasi tentang bencana.Sementara hard power adalah upaya menghadapi bencana dengan pembangunan fisik sepeti membangun sarana komunikasi, membangun tanggul, mendirikan dinding beton, mengeruk sungai dll. Dalam UU, dua hal ini yang disebut mitigasi bencana. Pada dua pendekatan inilah, komunikasi bencana amat dibutuhkan.

Strategi komunikasi adalah serangkaian tindakan yang direncanakan dengan baik untuk mencapai tujuan tertentu dengan menggunakan metode, teknik, dan pendekatan komunikasi. Ada tiga pendekatan dalam strategi komunikasi menurut Berger (Griffin, 2006:130), yaitu strategi pasif, aktif, dan interaktif. Di antara ketiga strategi tersebut, pendekatan interaktif yang telah digunakan dalam penelitian ini karena pendekatan ini tampak lebih mengedepankan nilai-nilai humanis serta budaya baru yang pada gilirannya mampu mengubah mind-set masyarakat tentang pembangunan.

\section{Peran Media Massa dalam Penanganan Bencana}

Penelitian mengenai peran media massa dalam penanganan bencana salah satunya dilakukan oleh Elva Ronaningroem dengan mengangkat judul "Persepsi Masyarakat tentang Peran Media Cetak Lokal dalam Mitigasi Bencana Alam". penelitian ini adalah untuk mendeskripsikan persepsi masyarakat dalam menafsirkan peran media cetak lokal Padang Ekpress dan Singgalang tentang mitigasi bencana alam.

Hasil penelitian mendeskripsikan Peran media lokal yaitu Harian Padang Ekpress dan Singgalang dipersepsi secara berbeda oleh kelompok buruh, pegawai negeri, mahasiswa, dan dosen. Menurut mahasiswa dan dosen, media lokal dapat mengurangi kepanikan masyarakat akibat isu-isu dan rumor yang tidak bertanggung jawab dan mendidik masyarakat agar lebih melek bencana. Menurut buruh dan pegawai negeri, media lokal terlalu mengekspos bencana secara berlebihan dan menyebabkan masyarakat kalut, bahkan eksodus ke luar daerah. Penelitian ini merekomendasikan agar media dan pemerintah serta lembaga yang terkait dengan bencana alam agar mengontrol pemberitaan tentang bencana alam sehingga tidak merugikan masyarakat (Elva, 2011).

\section{Komunikasi Antar-budaya Korban dan Relawan Bencana}

Penelitian dilakukan Mahyuzar dengan judul "Dinamika Komunikasi Antarbudaya Pasca Tsunami (Studi Dramaturgis dalam Kegiatan Kemasyarakatan Antar Warga Korban Tsunami dan Interaksi dengan Orang Asing di Banda Aceh). Penelitian ini bertujuan untuk mengkaji proses perubahan dalam perilaku berkomunikasi korban tsunami yang berbeda budaya. Penelitian ini mengambil lokasi di dalam wilayah Kota Banda Aceh. Penelitian menggunakan pendekatan kualitatif dengan tradisi interaksi simbolik khususnya dengan varian dramaturgi. Sebagai suatu acuan untuk menggali informasi dan persepsi serta melihat perilaku komunikasi para 
informan sebagai subjek penelitian. Data diperoleh dengan carawawancara mendalam, pengamatan berperanserta, dan studi dokumentasi. Teknik analisis data dilakukan secara deskriptif kualitatif

Hasil penelitian menunjukkan bahwa; pertama, identitas diri yang ditampilkan saat melakukan suatu kegiatan oleh individu mengharapkan dapat dipersepsikan positif. Dengan cara menutupi kelemahan yang ada dalam dirinya dengan menampilkan sebaliknya agar dapat diterima oleh kelompoknya dan orang lain. Kedua, warga korban tsunami di Banda Aceh masing-masing menampilkan perannya dengan melakukan pengelolaan kesan (impression management) sehingga tampak tegar atau menunjukkan lebih baik dari orang lain yang sama-sama mengalami musibah tsunami. Demikian juga untuk menampilkan kepada masyarakat luar bahwa kondisi kehidupannya kini sudah sama seperti masyarakat biasa yang tidak tertimpa tsunami, namun secara ekonomi (finansial) masih mengharapkan bantuan untuk menopang kebutuhan hidupnya dan sebagai modal usaha (Mahyuzar, 2011).

Berdasarkan hasil penelitian yang telah dilakukan, penulis dapat menghasilkan temuan baru tentang strategi komunikasi dalam kesiapan menghadapi bencana longsor bagi masyarakat kawasan pertanian di kaki gunung Burangrang, kab.Bandung Barat. Adapun hasil penelitian ini, penulis uraikan dalam deskripsi sebagai berikut.

1. Aparat desa/ tokoh masyarakat yang sebagai sumber yang kredibel
Melakukan observasi ke beberapa daerah yang rawan Bencana. Berbicara tentang strategi komunikasi, tentu tidak akan lepas dari upaya yang akan dilakukan berkaitan dengan unsurunsur komunikasi di dalamnya. Unsur komunikasi yang pertama disini adalah sumber/ komunikator. Penuturan dari beberapa informan menyatakan bahwa mereka memilih sumber yang kredibel, tentu yang mampu memberikan informasi kepada khalayak jika terjadi tanda-tanda bencana longsor akan terjadi. Hal ini dilakukan untuk meningkatkan kesiapan masyarakat dalam menghadapi bencana.

2. Pemilihan pesan yang mudah diterima oleh masyarakat

Langkah selanjutnya yang ditemukan dalam penelitian ini adalah pemilihan pesan yang mudah diterima oleh masyarakat Kabupaten Buton Selatan. Hal ini diupayakan agar pesan yang disampaikan pun, khususnya tentang tanda-tanda bencana mudah dipahami oleh masyarakat.

3. Penggunaan media komunikasi yang sesuai dengan karakteristik masyarakat kawasan pertanian

Penggunaan media tradisional sebagai media komunikasi yang sesuai dengan karakteristik masyarakat di lokasi penelitian. adanya penggunaan media komunikasi yang dipilih untuk menyampaikan pesan kepada masyarakat luas, khususnya berkaitan dengan kesiapsiagaan masyarakat jika terjadi bencana.

Sebagaimana diketahui juga bahwa media komunikasi tradisional sendiri terdiri dari beberapa macam bentuk dan jenisnya antara lain adalah bentuk-bentuk folklore seperti cerita rakyat 
(mitos, legenda, dongeng), ungkapan rakyat (peribahasa, pepatah, pomeo), puisi rakyat, nyanyian rakyat, teater rakyat dan alat-alat bunyian seperti kenthongan, gong, bedug, gendang dan sebagainya (Rachmadi, 1988: 111).

4. Pemahaman karakteristik masyarakat kawasan pertanian

Tentang karakteristik dari masyarakat ini yang kental dengan unsur lokal. . Inipun yang telah disampaikan dalam point sebelumnya mengenai penggunaan media komunikasi tradisional yang dipilih sesuai dengan karakteristik masyarakat.

5. Mengatasi hambatan komunikasi yang terjadi selama pelaksanaan strategi komunikasi tersebut.

Hambatan komunikasi lainnya yaitu hambatan waktu. Sebagai bagian dari warga desa, Rm juga menyampaikan adanya masalah dari konteks waktu, misalnya jika bencana longsor tersebut terjadi pada tengah malam, hal ini relatif sulit untuk memberitahu warga desa karena mayoritas warga dalam kondisi tidur. Jadi, diperlukan adanya evaluasi dan koordinasi yang berkelanjutan demi mengantisipasi tercapainya strategi komunikasi yang efektif bagi masyarakat dalam kesiapan menghadapi bencana.

\section{Analisis Teori AIDDA}

Salah satu teori komunikasi persuasif yang menggambarkan tentang strategi komunikasi adalah teori AIDDA. Dalam berkomunikasi, untuk mencapai suatu tujuan yang diharapkan, seorang komunikator harus memiliki strategi komunikasi yang baik. Adanya proses pendekatan merupakan awal yang baik dalam berkomunikasi. Proses pendekatan dapat dilakukan dengan menerapkan A-A Procedure atau from Attention to Action Procedure.

Menurut Kasali (1992, 83-86), A-A Procedure ini sebenarnya adalah penyederhanaan dari suatu proses yang disingkat AIDDA.

1. A Attention (Perhatian)

2. I Interest (Minat)

3. D Desire (Hasrat)

4. D Decision (Keputusan)

5. A Action (tindakan)

Proses tahapan komunikasi ini mengandung maksud bahwa komunikasi hendaknya dimulai dengan membangkitkan perhatian atau attention. Dalam penelitian ini, komunikator harus menimbulkan daya tarik/ perhatian (Attention). Hal ini dimulai dengan upaya menimbulkan perhatian masyarakat akan pentingnya berkoordinasi dalam menimimalisir dampak kerugian dari bencana longsor di desa tersebut.

Langkah keduanya, mendorong adanya minat (Interest), komunikasi dengan membangkitkan perhatian akan menjadi suatu awal suksesnya proses komunikasi. Apabila perhatian komunikan telah terbangkitkan, hendaknya disusun dengan upaya menumbuhkan minat atau interest, yang merupakan derajat yang lebih tinggi dari perhatian. Minat merupakan kelanjutan dari perhatian yang merupakan titik tolak bagi timbulnya suatu hasrat atau desire untuk melakukan suatu kegiatan yang diharapkan oleh komunikator.

Hasrat (Desire), dalam penelitian ini, pihak Kepala Desa berkoordinasi dengan tokoh 
masyarakat dan aparat lain untuk memunculkan adanya hasrat kesadaran dalam meminimalisir dampak kerugian dari bencana. Pihak desa berupaya agar masyarakat memiliki hasrat kesadaran untuk bersama-sama menimimalisir kerusakan sebagai dampak dari bencana.

\section{SIMPULAN}

Komunikasi dalam bencana tidak saja dibutuhkan dalam kondisi darurat bencana, tapi juga penting pada saat pra bencana.Mempersiapkan masyarakat di daerah rawan bencana tentu harus senantiasa dilakukan. Selain informasi yang memadai tentang potensi bencana di suatu daerah, pelatihan dan internalisasi kebiasaan menghadapi situasi bencana juga harus dilakukan secara berkelanjutan.Tapi harus diingat, informasi berlimpah saja tidak cukup untuk menyadarkan warga atas bahaya bencana yang mengancam. Cara menyampaikan informasi juga harus dilakukan dengan tepat. Kekeliruan dalam mengkomunikasikan sebuah informasi, bisa menimbulkan ketidakpastian yang memperburuk situasi. Dalam situasi ini, pendekatan komunikasi budaya dan lintas budaya amat dibutuhkan.

Hasil penelitian yang telah dilakukan menunjukkan adanya strategi komunikasi interaktif dalam kesiapan menghadapi bencaana.

Penentuan aparat desa/ tokoh masyarakat sebagai komunikator/ sumber yang kredibel, Pemilihan pesan yang mudah diterima oleh masyarakat di kawasan kaki gunung Burangrang, Penggunaan media komunikasi yang sesuai dengan karakteristik masyarakat, Pemahaman karakteristik masyarakat, Mengatasi hambatan komunikasi yang terjadi selama pelaksanaan strategi komunikasi tersebut.

Dalam penelitian yang telah dilakukan ini, penulis ingin memberikan saran yaitu sebaiknya sinergitas antara pemerintah daerah, kantor desa, tokoh masyarakat, RT, RW, dan lembaga terkait yang telah berjalan tetap dipertahankan dalam mewujudkan strategi komunikasi interaktif dalam kesiapan menghadapi bencana bagi masyarakat Kabupaten Buton Selatan

\section{DAFTAR PUSTAKA}

Haddow, G. D, dan Kims. (2008). Disaster ComMunications, In A Changing Media World. London. Elsevier

Mulyana, Deddy.(2002). Metodologi Penelitian Kualitatif. Bandung: PT Remaja Rosdakarya.

Mahyuzar. 2011. Dinamika Komunikasi Antarbudaya Pasca Tsunami (Studi Dramaturgis Dalam Kegiatan Kemasyarakatan Antar Warga Korban Tsunami Dan Interaksi Dengan Orang Asing di Banda Aceh. Bandung: Disertasi Program Doktor Ilmu Komunikasi UNPAD.

Rachmadi, F. (1988). Manfaat Media Komunikasi dalam Pembangunan Masyarakat dalam Media Rakyat; Komunikasi Pengembangan Masyarakat, Editor: Manfred Oepen. Jakarta: Perhimpunan Pengembangan Pesantren dan Masyarakat (P3M).

Ramli, Soehatman. (2010). Sistem Manajemen Keselamatan \& Kesehatan Kerja OHSAS 18001. Jakarta : Dian Rakyat

Rangkuti, Freddy. (2009). Strategi Promosi yang Kreatif dan Analisis Kasus Integrated Marketing Communication. Jakarta : PT. Gramedia Pustaka Utama

Sugiyono. (2006). Metode Penelitian Pendidikan, Pendekatan Kuantitatif, Kualitatif dan R\&D. Bandung: Penerbit Alfabeta

Yin, Robert K. (2006). Studi Kasus (Desain dan Metode). Jakarta: Raja Grafindo Persada 


\section{Jurnal}

Lestari, P., Prabowo, A., \& Wibawa, A. (2014). Manajemen Komunikasi Bencana Merapi 2010 pada saat Tanggap Darurat. Jurnal Ilmu Komunikasi (JIK), 10(2).

Abadi, T. W., \& Mahendrawati, I. K. (2012). Penertiban Versus Penggusuran: Strategi Komunikasi dan Partisipasi Pembangunan (Studi Kasus di Stren Kali Jagir Wonokromo-Surabaya). Scriptura, 3(2), 112-128. 